\title{
Adaptation in South Korean Society of North Korean Elite Defectors
}

Nicolas Levi

Institute of Mediterranean and Oriental Cultures

of the Polish Academy of Sciences, Poland

e-mail: Nicolas_levi@yahoo.fr

\begin{abstract}
:
This paper aims to explain the adaptation of North Korean elite defectors who fled from North Korea. Data used for the purpose of this article came from surveys of North Korean defectors conducted in the late 2000's. Findings of the realized research indicate that the majority of senior defectors are experiencing less psychological and material issues when adjusting to society than regular North Korean defectors. The paper will proceed in three steps: explaining the notion of defectors, outlining their background, and focusing on their adaptation in South. Although defectors as a whole has emerged as of the most research group as a minority in South Korea, the so-called senior defectors have hardly been spotlighted. Basically North Korean senior defectors are supposed to strengthen the anti-Kim movement and legitimize the power of the South Korean government and the image of South Korea abroad. What has to be enlightened upon is the fact that North Korean senior defectors partially disagree with the integration policy of South Korean authorities. A major research question emerges: How are the experience of elite defectors localized in South Korea? How do their specific identities impact their opinion within the South Korean society? The aim of the article is also to categorize senior defectors and to provide in a single document a list of senior North Korea defectors based abroad. This kind of information is only available for Korean speaking readers. I wanted to make it accessible to the Englishspeaking community.

Keywords: adaptation, cultural differences between both Koreas, integration in South Korea, North Korea, North Korean elites, North Korean senior defectors.
\end{abstract}




\section{Introduction}

This article presents the results of a study of North Korean senior defectors (고위탈북자 - Koui Talpukja) who escaped their home country and living now abroad. It provides also a historical account on the changing social definitions of North Korean defectors. It also provides an account of the difficulties of these individuals whose identities are between "defector" and "migrant", the problems they face in capitalist South Korea are examined in the major areas of social changes consumption, education, ideology, and work. To my humble knowledge, there are no published papers dedicated to the differences in experiences and adaptation of different groups of North Korean migrants to South Korea. According to Andrei Lankov, elite defectors represent 10 percent of the total number of refugees [16, p. 96]. There are around 28,000 defectors in South Korea. At the end of the article, the reader will find a list of senior defectors who defected abroad. No documents like this are available in western languages.

\section{Objectives}

First, the author analyzed the roots of North Korean defections. Secondly, this article discusses, the adaptation of North Korean senior defectors to the South Korean one. In particular, this integration could be changed through changes of views on defectors by the South Korean population and by massive and regular campaigns. Third, the text provides some information related to the adaptation of defectors to other societies than the South Korean one.

\section{Research Questions}

This article addresses the following research question: For which purposes North Korean elites are leaving their home country and to what extent even elite defectors have difficulties to integrate and to assimilate to the South Korean society.

\section{Theoretical Framework}

This empirical research is based on adaptation and identity theories. According to Eric Erickson, the identity must fit into the larger society in order to reduce the unsuccessful outcomes of identity formation [8, p. 47]. These include "negative identity" based on opposition to others' wishes. According to Wenger, socio-cultural learning theory argues that people learn through engagement with actions and interactions and participations within socio-cultural and historical contexts. Participation "refers not just to local events of engagement in certain activities with certain people, but to a more encompassing process of being active participants in the practices of social communities and constructing identities in relation to these communities" [19, p. 4]. I will consider that adaption may be related to three areas: psychological, sociocultural, and economics [4, p. 6]. Psychological adaptation means interaction between environment and behavior, sociocultural is the adaptation to the society and economics adaptation is the behavior in a society with new economic rules.

Another suitable framework for the examination of adaptation of North Korean defectors is the one developed by the South Korean researcher Kim Young-yun. He prepared a relevant theoretical framework which is related to the adaptation of refugees. Kim conceptualizes an adaptation as an interplay between the person and the environment. According to Kim, humans have a capacity to adapt themselves to environmental challenges, secondly, the adaptation of an individual in a different cultural environment occurs through communication. Finally, the process of adaptation is a dynamic process that brings about qualitative changes of the considered individuals. Kim believes that in a new environment, human beings have the natural tendency to adapt. The process of adaptation takes place through communication where partners gets information and 
responds to information [20, p. 28]. According to Paulisch, being a defector is only a temporary situation [1, p. 119].

From the theoretical political background, these North Korean elites belong to the first class of North Korean citizens. According the North Korean class system (Songbun) established in 1957 on a decree entitled "On the transformation of the Struggle with Counterrevolutionary Elements into an All-People All-Party Movement" passed by the Politburo for the WPK, there are 3 major social classes (kyechung) according to the degree of loyalty toward the WPK and the parental background of the population. The core class (haksim kyechung) is composed of bereaved families of the Korean War. The second class (tongyo kyechung) consists of some merchants, who may act against the regime and intellectuals [15, p. 185]. The third class is called the antagonist one (choktae kyechung) considered as antagonist to the regime, such as landlors and capitalits ${ }^{1}$. These senior defectors are defined in the present article as people belonging to the haksim kyechung. They are usually either members of the Korean Workers' Party, or citizens of Pyongang, people with a high education, people who travelled abroad and in the majority men. Interestingly, defectors of the tongyo or chokate classes are usually women, who left their country for economic reasons.

Finally I would like to introduce the concept of acculturation which is a cultural change resulting from contacts between two cultural groups [2, p. 69]. I do consider here that North and South Korean are similar but only to a certain extent. They do have a similar language, some similar dishes and games but basically they developed each other in a different environment. The concept of assimilation needs also to be note in this article. According to Berry, structural assimilation is a high degree of contact and participation, regarding cultural assimilation, it's a high degree of cultural mix [4, p. 12].

\section{Hypothesis}

In preparing the present article, I have hypothesized that most senior defectors do not interact with foreigners due to their limited speaking capability. They do not have real interactions with other communities than the Korean one. Therefore, foreign South Korean communities play a role of adjustment environment for North Korean senior defectors. I also consider that North Koreans who are abroad are only temporary defectors. After an adaptation period, they must adapt and adjust themselves to their new environment.

\section{Methodology}

Generally speaking, on a regular basis, surveys are conducted in order to get a better understanding of North Korean defectors. Nevertheless, surveys focused on North Korean senior defectors are barely available. It's probably due to the sensitivity of the positions of these former North Korean people. Another important issue is the fact, that many senior defectors are afraid to speak out even under the condition of anonymity. They feared of being murdered or excluded by the defectors community. I must recognize the dubious practices that underpin most research articles based on interviews with North Koreans living in South Korea as all that North Koreans do and say in South Korea is heavily surveilled by the South Korean intelligence services, some are even afraid that if they speak out against the approved narrative, they fear being murdered. Finally, I must also underline that there are some limitations on the preparation of this research article as access to North Korean senior defectors is highly difficult especially during the worsening of relations between both Koreas. It's clearly affecting the quality and the potential of this research paper.

\section{The Notion of Defector}

First overall, the division of the Korean Peninsula is a result of the World War II. Around 65 years ago, important differences emerged between both Koreas. Since the 60s, many North Koreans are risking their lives to cross the border between both Koreas. Leaving their home country without a 
permission is still considered as being illegal under the North Korean criminal code (북한형법 Pukhan Hyongbom). Since the end of the Korean War 1953, 300,000 North Koreans fled abroad mainly to China and Russia. Most of whom have gone to Russia or China. Religious groups supporting defectors consider, that there are more than 1,000 defectors in Russia and approximately 100,000 - 200,000 in China [12, p. 3]. Between 1950 and 1989, 607 North Korean defectors arrived in South Korea. From the 1990s, North Koreans began to move to China in large numbers. To cross the border between North Korea and China is not an unreachable task as both countries are separated by the Tumen and Yalu river which is narrow, and frozen during winter times. As of the end of 2015, there are 28,597 North Korean defectors established in South Korea. Based on a study of South Korean defectors, women are the majority of defectors. As of 2002 they represented around 56\% of defections to South Korea (1,138 people) and in 2011 the figure rose 71\% (2,706 people). More women leave the North because they suffer of economic difficulties. Being employed in the service and administration sectors, they earn low salaries [9]. Men still mainly defect for political and ambition reasons as their aspirations are limited on North Korea. In South Korea there are different ways of calling defectors. The average North Korean defector is a poor woman from the Northern part of North Korea. In comparison, the typical Soviet defector was a member of the Soviet Intelligensia. As I mentioned previously, senior defectors represent $10 \%$ of the global population of defectors. Secondly defectors had been granted different identities taking in account the historical timeframe. Several terms are referring to North Korean refugees. Until 1993, North Korean defectors were called kwisunsa (귀순자 - defectors) or kuisunyongsa (귀순용사 - brave defectors), between 1994 and 1996 Ttalpukja and kuisunpukhantongpo (귀순북한동포). Between 1997 and 2004, two appellations were used: Ttalpukja (탈북자 - “people who fled the North”) and Pukhanitaljumin (북한이탈주민 - "people, who renounced from North Korea"). Starting from 2005, the South Korean Ministry of Unification (통일부 - Tongilbu) started to use the term of saeteomin (새터민 - "people of new land") instead of ttalpukja, a term unappreciated by North Korean officials.

\section{Motives of Defections}

Regarding motives of defections, according to the South Korean researcher Sung Hong-ko, on a global scale until the early 1990s, motives were rather political, because people were dissatisfied with the North Korean regime and its policy. Those who defected were diplomats based abroad, soldiers, students and traders based abroad and representing North Korean companies. Later, starting basically from 1995, the economic motive was prevalent due to the food crisis [10, p. 75]. Since the mid 1990s, defecting women became also more dominant especially from the northern parts of North Korea (from the following provinces: Jjagang, North Hamgyung, North Pyongan, and Ryanggang). Interestingly not only people with a low-background are going to South Korea. Some North Korean elites are also moving from their former country for the following reasons. The first one is that these people do not feel secure in their own country, this argument is prevalent for important for North Korean defectors who belonged to the key structures of the North Korean apparatus (Korean Workers' Party, Korean People's Army, Foreign Trade North Korean Company). As examples we can quote the personalities of Hwang Yan-yop, the initiator of the North Korean ideology, the Juche, and the chief political ideologue; Choe Kun-Chol - former Regional Korean Workers' Party Secretary).Regarding regular North Korean defectors, they used to defect because of economic issues and to a lower extent because they were in position of being threatened, because they expressed some kind of scepticism over the North Korean system or feared that it may collapse. In April 1991, Ko Young-hwan, a former diplomat at the North Korean embassy to Zaire was in a way afraid that a similar situation to the execution of Nicolae Ceaucescu may happen in North Korea. One month later Ko defected as he was afraid of being sent back to Pyongyang for his 
remarks. As of now he lives in South Korea and works as a senior analyst for Unification organizations.

\section{Classification of North Korean Defectors}

According to the South Korean researcher Sung Ho-ko, the Koreans exist as a single ethnic group for more than 2000 years. Following the Korean War $(1950-1953)$, the situation of Korean evolved quickly. The number of defectors started to increase with economic problems of North Korea in the 80 's. Before there were no real cases of defections. For example, there were only 59 defectors from 1971 till 1980. People within the North Korean defectors community differ in their sense of identification with South Koreans. Despite of having a common history until 1950, the Korean and Cold Wars created two distinct countries. The degree of intensity with which they share majority beliefs. Some of them identify to Koreans, some other feel that they are foreigners in South Korea. North Korean elite defectors can use one of the various subterfuges to enter into South Korea or a foreign country. They may try to defect while being abroad (Hwang Jang-yop, Kim Dokhong) or by using a kind of Very Important Person treatment (quick transfer to South Korea via direct flight from Shenyang to Seoul, etc.) [7, pp. 239 - 247]. Some of these elite defectors are freedom fighter. These people try to improve the situation of their country-mates who are still in North Korea. Other elite defectors are the members of the Kim family who avoid to appear in public. Their position is more neutral than the others mentioned previously. These people defected in any cases for economic reasons. They defected either for political (Hwang Jang-yop) or philosophical reasons (Ri Han-Yong). Some of these North Korean elite defectors moved to the US. Two of them are Ri Kang and Ko Yong-Suk. Both of them belong to the ruling Kim family in North Korea. They supposedly moved for freedom reasons to a third country and finally established in the United States at an undisclosed localization. Ri Kang is running a laundry business. Their three children are studying in different states of the United States [11]. Other members of their family defected earlier. One of them is Ri Han-yong. Ri Han-yong's mother was Song Hye-rang, a sister of Song Hye-rim, and a former mistress of Kim Jong-il. He studied mainly in Moscow, travelled all over Europe (including Poland) and for freedom reasons, defected to South Korea in 1982 during his studies in Switzerland. Globally speaking, the integration in South Korea is very upsetting and stressful for North Koreans. The majority of North Korean defectors identify themselves as North Koreans [17]. They usually feel stressed in South Korea Nevertheless, those who are too much depressed, are moving to other countries face with a different other level of difficulties. In spite of their education, many North Korean elite defectors faced with language barriers and to a lower extent in comparison to life in South Korea, fail to adapt to their new life. Some of them were educated in former communist countries and may speak in Russian or other similar languages as they used to study in foreign universities. Some of them have a limited knowledge of foreign languages as they started to study in foreign countries and learnt basic of a specific language (usually the mother tongue of the country where they studied). Otherwise the majority of elite defectors, that I identified, do not speak in English, none of them were living in an English-speaking country. Basically out of South Korea, North Korean elite defectors tend to live either with other Koreans in Korean towns (like in Los Angeles or in New Malden, a suburb in south-west of London) but to a lower extent than regular North Korean defectors.

\section{North Korean Elite Defectors and Their Adaptation to South Korea}

According to John Berry, adjustment can be considered as being a process of an individual coming into harmony with various conditions and circumstances [3]. This article defines the adjustment of North Korean defectors as a complex issue of inter-cultural adaptation. In spite of similar language and common ethnicity, North Korean defectors shall adjust more or less to South Korean society. Regular North Koreans defectors experienced great difficulties and challenges and do not adapt to the South Korean society. A limited number of defectors can be considered as experiencing a real 
"adjustment" or "integration". The majority of them are first workers and traders who works in foreign currencies companies, secondly former Central and Eastern European students, and thirdly diplomats who were based abroad. All of them were exposed to foreign systems and therefore possess knowledge and skills. Therefore some created successful commercial activities in South Korea such as Choe Sae-ung (최세웅), the owner of an exchange company [22]. Other successful adjustments are realized by those who starts a new University education in South Korea. Except education they are also educated to South Korean manners. Later they may get a job in the South Korean administration however they are more successful by running their own businesses.

What needs to be underlined is the so-called socioeconomic background of these defectors. If they had a high social status in North Korea, their social adjustment is done easily and they remain to a certain extent to the same social position. Any downgrading is still limited. That's why all of that leads to the creation of class differentiation between Korean defectors. Defectors who either worked in foreign trade companies, or were students in foreign countries are said to have adapted most successfully, as they were already used to a different society from the North Korean one. For example, one defector arrived to South Korea during the summer 1990, and operates currently an IT software production entity. He obtained a degree of Applied Mathematics at the University Khabarovsk, in the state of Russia. Through utilizing his network, when he came to South Korea, he imported less expensive, skilled programmers from Russia to create IT products [21]. Lee Chong-guk, a son of an elite clan, who was a cooker at Chongryugwan, the most famous of all Pyongyang restaurants, established his own restaurant chain in South Korea.

Sin Yong-hui, dancer in the Mansudae troupe became a moderately successful actress. The father of her husband was working in the financial department of the KWP. Her husband Choi Seung, worked for many years in the overseas offices of North Korean trade companies, founded a highly successful company that deals in currency exchange. The creation of self-companies seems to be more profitable for these senior defectors than working in regular companies. It may be due to the fact, that they are not discriminated, being the owners of their own business. Many of these defectors who were working in foreign Furthermore, North Korean elite defectors used also to be students in the best universities. In spite of having no access to Internet while being in North Korea, at their universities they used on a regular basis "decent" computers, used the North Korean Intranet and therefore have IT skills [7, p. 277].

In opposition, the Russian researcher Andrei Lankov considers that even elite defectors are facing challenges in South Korea. They have trouble to find a prestigious job, because their potential employers feel suspicious about their origins and lacks of networks. North Korean elite defectors belong in any cases to networks from people from the same region, same university, or same clans [16, p. 98]. Therefore, even elite defectors feel lonely in South Korea.

North Korean elites who are defecting to South Korea have a special treatment upon their arrivals. These elites are used by South Korean Authorities in order to obtain a better understanding of the North Korean reality [12, p. 10]. Based on research conducted by the Center of Unification (Tongilbu 통일부), many North Korean are considered as being welcomed upon their arrival in South Korea. Regarding North Korean elites, due to their special statue, these people are considered as regular North Korean escapee or Heroic Defector. Heroic defectors are mainly related to people who escaped North Korea at the beginning of the Cold War. We can quote No kum-sok, an Air Force senior lieutenant who flew North Korea on the 21th September 1953. He resides now in the United States. Kim Shin-jo, a member of a group which was supposed to assassinate Park Chunghee in 1968 (the so-called Simildo Incident). He lately became a missionary and help North Korean to defect in South Korea. Finally, we can quote Jang- Gil-su, a child who defected and depicted the North Korean reality of Labor Camps (Kwanliso). Due to integration problems, many senior defectors are rather entering research institutes than private or own business. In these private institutions, they sell their knowledge. Nevertheless, supply of jobs within these institutions is more than limited especially taking in account that South Korean institutions are cutting funds for these research centers. Some of these elite defectors met with the regular defectors community through the participation to broadcasted South Korean TV shows such as Ijae Mannaro Kamnida 
(이제만나러갑니다 - “on my way to meet you”) or Pukhan Suda (북한수다 - "meetings with North Korea"). The senior defector Kang Myong-do is participating to the first one. Some of these North Korean defectors are one of the main source of information for the South Korean government and affiliated institutions. Elite defectors are those who can provide more valuable information as being in the past inside the North Korea system. These elites tend to make more money from their research activities than from working in a regular company. Many North Korean senior defectors have an aversion towards organizational life. They still are sceptical and considered as unwanted by South Koreans in South Korea and abroad [13]. The majority of other defectors are working in North-South Organizations. Interestingly, the majority of them are still in touch with North Korean authorities or people (North Korean and foreigners) living in North Korea. Some of these senior defectors do not feel secure in North Korea, and have financial problems (such as Lee Myong-Kuk or the deceased Ri Han-yong). Therefore, they publish book telling their histories in North Korea. For example, Ri Han-yong authored a book called 대동강로열패밀리 - the Taedong River Royal Family: my 14 years incognito in Seoul] and published in 1996. Hwang Jang-yop, the former North Korean KWP Secretary who escaped in 1997, published also more than 10 books, being in South

Korea (the most famous is 나는역사의진리를보았다 - I was a witness of History, written by Hwang Jang-yop) [12, p. 5]. Some of elite family members are defecting while being abroad. We can quote for example, Ri Eun-kyong, the daughter of Choe Sam-suk (a famous North Korean actress) who escaped while working in a North Korean restaurant or Hwang Jang-yop who escaped during a trip to Beijing. Regarding him, he defected probably for political reasons being feared of a purge in North Korea. Hwang Jang-yop mainly mentioned that he defected for freedom issues, but being a high dignitary while in North Korean, we can put in question his motive for leaving North Korea. His statue was very high, he was practically a member of the Kim family and the initiator of the Juche (self-reliance) ideology. Therefore, I consider that he defected because he felt unsecured in North Korea.

An important category of senior defectors are nuclear scientists. North Korean nuclear scientists who defected are literally caught either by South Korean or American authorities. They are supposed to possess the most important information regarding the military system of their former country in the eyes of the United States and South Korea. One of them is Kyong Won-ha, the so-called father of the North Korean nuclear program. He defected during the operation Weasel in March 2003. Some other North Korean scientists defected also through the currently closed embassy of Nauru in Beijing. Most of them live now in the United States, where they feel more comfortable than in South Korea as they feel less stressed and living in a more friendly environment [14, pp. $15-21]$.

Interestingly, in spite of their material situation, some of the North Koreans elite defectors are re-defecting by leaving South Korea to another western country. We can quote for example Lee Young-kuk. With his family, he was living in South Korea and finally moved from this country. This former bodyguard of Kim Jong-Il reached Canada in March 2016. He fled South Korea and became an asylum seeker, claiming against threats and persecution by South Korea for his outspoken criticism of the North Korean regime [5].Their defections are due from one side to adaptation problems in South Korea, but also in the seeking of new challenges. The key adaptation problem is related to long-term issues and financial one. The adaptation issue is due to a lack of recognition by South Korean citizens. For regular defectors they do have a double adaptation problem. First, they need to understand the technology and the way of living of South Korean people. Then, they need to fit to the South Korean society getting in interactions with them. Regarding senior defectors their major problem is related to psychological, and sociocultural issues. They do face difficulties to find friends within South Korean people, due to their former songbun, they do not feel also comfortable with regular South Korean habitants. In North Korea, they were highly respected. At their arrival in South Korea, they became regular citizens with some extra financial benefits but nothing else. Regarding economic matters, they usually use their maintained background for developing a business in South Korea. The economic aspect is the base for their 
integration in South Korea where South Korean citizens consider that the economic success is a key element of mutual acceptation. However, their total integration cannot be pursued as the South Korean society cannot be considered as a framework explicitly open to foreigners and different cultures. North Korean felt prejudiced in South Korea and thus refuse assimilation. That's why usually North Korean defectors remain in their own community with their own system of value. It's less true for elite defectors who based their integration and then recognition by South Korean citizens on economic issues. These senior defectors are better assimilated than regular ones. They also accept the assimilationist policy of the South Korean government and accept to be a part of the major group of the population. They fit with the structural assimilation but accept to a lower extent the cultural assimilation by spending their free time only with other senior defectors.

\section{Conclusion}

In spite of their material situations, some North Korean elites decide to defect abroad. They defect mainly for safety reasons as they do benefit from financial advantages in North Korea, as they belong to the haksim kyechung, nevertheless in spite of this, they do not feel secured in North Korea and may defect. After the defection process, North Korean senior defectors adapt themselves to the South Korean society by working in institutions dealing with North Korean Issues or running their own businesses. They are working either in public institutions (Ministry of Unification, The Committee for the Five Northern Korean Provinces (이북 5 도위원회 literally "The North's Five Provinces Committee" - a South Korean government body under the Ministry of Security and Public Administration) or private institutions (Free North Korea Broadcasting - 유북한방송 Jayu Pukhan Bangsong). As I mentioned earlier, some of them feel persecuted or cannot adjust to the South Korea society and are looking for asylum in other countries especially in Canada, the US and Europe, and Japan [6, p. 97].

The majority of these elite defectors adjusted with difficulties to the South Korean or foreign societies due to a theoretical problem of communication-adjustment. Nevertheless, some of these senior defectors such as former students or business representatives in foreign countries have less difficulties out of South Korea. Therefore, the major adaptation problem for North Korean elite defectors is not related to economic issues, but to sociocultural ones and to their socialization. They face huge difficulties to get back their position they obtained in North Korea. And that's their major adaptation problem. Therefore, most of them consider that working for the Korean Unification can improve their sociocultural adaptation (even in spite of the fact they were not keen on this topic being based in North Korea). Consequently, many of the North Korean elite defectors can be categorized as being openly "Freedom fighters". Those who are based out of South Korea are usually not fighting, at least officially, for the freedom of North Korea or the Unification of both Koreas. Those who are belonging to the Kim family are sometimes showing openly their harsh criticism of the North Korean regime (Ri Han-yong, Hwang Jang-yop), however to a lesser extent than other senior defectors. Some of defectors are also going to North Korea however it's still a minority [18].

\section{References}

1. Baue, $\mathrm{G}$ and M. Paulitsch.An investigation of membership and clique avoidance in TTP/C, In Reliable Distributed Systems, 2000. SRDS-2000, Proceedings The 19th IEEE Symposium on IEEE, pp. 118-124.

2. Berry, J. W. Acculturation and adaptation in a new society, International migration 30, 1992.

3. Berry, J. W. Finding Identity: Segregation, Integration, Assimilation or Marginality, in Ethnic

Canada: Identities and Inequalities, Toronto: Copp Clark Pitman, 1987, pp. 223-239.

4. Berry, J. W. Immigration, acculturation, and adaptation, Applied psychology 46, 1 (1997).

5. Bodyguard to Kim Jong-il seeks asylum in Canada, The Hamilton Spectator, 4th April 2016. 
6. Chang-ho, L., M, Sung-kil, J. Woo-taek, M. Kigawa, and M. Sugawara, Mental health and quality of life of North Korean defectors living in Japan, Asian Journal of Psychiatry, Vol. 2, No. 3, October 2009.

7. Demick, B. Nothing to Envy - Ordinary Lives in North Korea, New York: Spiegel \& Grau, 2010.

8. Erickson, E. Identity: Youth and crisis, New York: Norton, 1968.

9. Hegarty, S. North Korea: Defectors adjust to life abroad, BBC News Magazine: http://www.bbc.com/news/magazine-22209894, (accessed: 23rd April 2013).

10. Ho-ko, S., Chung, K. and Yoo-seok Oh. North Korean Defectors: Their Life and Well-Being After Defection, Asian Perspective, vol. 28, No., 2004.

11. I defected after seeing North Korea regime 'cruelty', says Kim Jong-un's uncle, "The Guardian", 10 $0^{\text {th }}$ December 2015 (accessed: 10th June 2016).

12. In-jin, Y. North Korean Diaspora: North Korean defectors abroad and in South Korea, Development and Society, vol. 30, no. 1, June 2001.

13. Interview with a North Korean elite defector. The interview was conducted in July 2015 in Seoul (South Korea).

14. Jong-sook, A. and K. Yang-soo. Communication Experiences of North Korean Defectors in Los Angeles: An Exploratory Interview Study of Cross-Cultural Adaptation, International Journal of Arts and Humanities, vol. 1, nr 1, June 2015, pp. 15-21.

15. Kimura, M., Okamura, M., and K. Futagami. An Interpretation of the North Korean Regime, The Journal of the Korean Economy, vol. 2, no. 1, Spring 2001.

16. Lankov, A. The Real North Korea - Life and Politics in the Failed Stalinist Utopia. New York: Oxford University Press, 2013.

17. Taek-jon, W. Issues and Problems of adaptation of North Korean defectors to South Korean society: An in-depth interview Study with 32 defectors, Yonsei Medical Journal, vol. 41, no. 3, 2000, pp. 362-371.

18. Taylor, A. Some North Korean refugees are so depressed by their life in the South that they go back North, Business Insider, $9^{\text {th }}$ August 2012.

19. Wenger, E. Communities of practice: Learning, meaning, and identity, New York: Cambridge University Press, 1998.

20. Young-yun, K. Becoming intercultural: An integrative theory of communication and crosscultural adaptation, Thousand Oaks, CA: Sage Publications, 2001.

21. 북한에남 한의 $M \& A$ 시장열어줘 야 (Pukhanae Namhanoe $\mathrm{M} \& \mathrm{~A}$ sijangyolojoeya - the $\mathrm{M} \& \mathrm{~A}$ market between North and South Korea must be open), 26th December 2011, NKSC News.

22. 최세웅사장은누구? 당고위간부출신 '엘리트', Oh My News, 4th August 2016.

ANNEX - Selected list of North Korean elites who fled to South Korea

\begin{tabular}{|l|l|l|l|l|}
\hline Identity & $\begin{array}{l}\text { Year } \\
\text { fled }\end{array}$ & Last position in North Korea & $\begin{array}{l}\text { Current } \\
\text { position }\end{array}$ & $\begin{array}{l}\text { Current } \\
\text { place } \\
\text { living }\end{array}$ \\
\hline $\begin{array}{l}\text { Choe Ju- } \\
\text { hwal }\end{array}$ & 1996 & $\begin{array}{l}\text { Deputy director at the Section 1 of } \\
\text { the Foreign Affairs Desk of the } \\
\text { Foreign Affairs Department of the } \\
\text { Korean People's Army }\end{array}$ & Researcher \\
\hline $\begin{array}{l}\text { Choe Kun- } \\
\text { chol }\end{array}$ & $\mathrm{n}$ & Unknow Korea \\
Pormer Regional Korean Workers' & $\begin{array}{l}\text { Advisor, New } \\
\text { Focus } \\
\text { International }\end{array}$ & South Korea \\
\hline $\begin{array}{l}\text { ChoeMyung } \\
\text {-chul }\end{array}$ & 1994 & Professor, Kim Il-sung University & $\begin{array}{l}\text { Politician, } \\
\text { Saenuri member }\end{array}$ & South Korea \\
\hline Choi Se-ong & Unknow & Foreign Trade official & Owner of a & South Korea \\
\hline
\end{tabular}




\begin{tabular}{|c|c|c|c|c|}
\hline & $\mathrm{n}$ & & $\begin{array}{l}\text { trading currency } \\
\text { company }\end{array}$ & \\
\hline $\begin{array}{l}\text { Choi Seon- } \\
\text { young }\end{array}$ & 1996 & North Korean official & $\begin{array}{l}\text { Journalist, } \\
\text { employee at the } \\
\text { North Korean } \\
\text { desk of the } \\
\text { South Korean } \\
\text { Press Agency } \\
\text { Yonhap }\end{array}$ & South Korea \\
\hline $\begin{array}{l}\text { Hwang } \\
\text { Jang-yop } \\
\text { (passed } \\
\text { away in } \\
\text { December } \\
2010 \text { ) }\end{array}$ & 1997 & 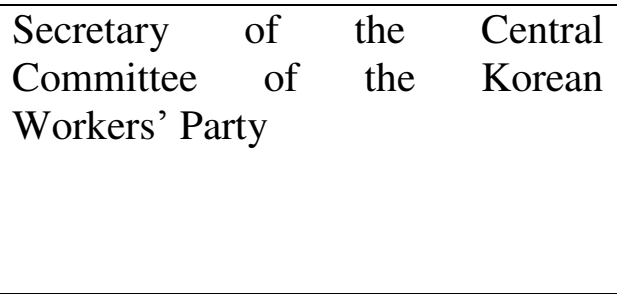 & $\begin{array}{l}\text { Former } \\
\text { politician }\end{array}$ & South Korea \\
\hline $\begin{array}{l}\text { Hyeon } \\
\text { Seong-il }\end{array}$ & 2009 & Diplomat & $\begin{array}{l}\text { Affiliated at the } \\
\text { Faculty of North } \\
\text { Korean Studies } \\
\text { of the Dongguk } \\
\text { University }\end{array}$ & South Korea \\
\hline $\begin{array}{l}\text { Im Young- } \\
\text { sun }\end{array}$ & $\begin{array}{l}\text { Unknow } \\
\text { n Date }\end{array}$ & Military officer & $\begin{array}{l}\text { Director at Seoul } \\
\text { Pyongyang TV }\end{array}$ & South Korea \\
\hline $\begin{array}{l}\text { Jang Jin- } \\
\text { sung }\end{array}$ & 2003 & Poetry, Propaganda Department & Writer, activist & Seoul \\
\hline $\begin{array}{l}\text { Jang Seung- } \\
\text { ho }\end{array}$ & 1997 & $\begin{array}{l}\text { Diplomat at the North Korean } \\
\text { delegation in France }\end{array}$ & $\begin{array}{l}\text { Unknown } \\
\text { function }\end{array}$ & South Korea \\
\hline $\begin{array}{l}\text { Jang Seung- } \\
\text { il }\end{array}$ & 1997 & $\begin{array}{lll}\text { North Korean Ambassador in } \\
\text { Egypt }\end{array}$ & $\begin{array}{l}\text { Unknown } \\
\text { function }\end{array}$ & $\begin{array}{l}\text { Unknown } \\
\text { localization }\end{array}$ \\
\hline $\begin{array}{l}\text { Joo Seong- } \\
\text { ha }\end{array}$ & 2002 & Professor, Kim Il Sung University & Journalist & South Korea \\
\hline $\begin{array}{l}\text { Kang } \\
\text { Myong-do }\end{array}$ & 1994 & $\begin{array}{l}\text { Director at a university under the } \\
\text { Ministry of the People's Armed } \\
\text { Forces. Step-son of Kang Song- } \\
\text { san, former North Korean Prime } \\
\text { Minister }\end{array}$ & $\begin{array}{l}\text { Researcher and } \\
\text { Professor, } \\
\text { Kyungmin } \\
\text { University }\end{array}$ & South Korea \\
\hline $\begin{array}{l}\text { Kim Cheol- } \\
\text { ung }\end{array}$ & 2002 & Pianist & $\begin{array}{l}\text { Researcher, } \\
\text { Donkkuk } \\
\text { University }\end{array}$ & $\begin{array}{l}\text { Unknown } \\
\text { localization }\end{array}$ \\
\hline $\begin{array}{l}\text { Kim Dok- } \\
\text { hong }\end{array}$ & 1997 & $\begin{array}{l}\text { President of Yogwang General } \\
\text { Trading Company and deputy } \\
\text { chief of the office of documents of } \\
\text { the Central Committee of the } \\
\text { Workers Party. }\end{array}$ & $\begin{array}{l}\text { Unknown } \\
\text { function }\end{array}$ & South Korea \\
\hline $\begin{array}{l}\text { Kim Dong- } \\
\text { sik }\end{array}$ & 1995 & $\begin{array}{l}\text { Official, North Korean delegation } \\
\text { of the World Food Organization }\end{array}$ & $\begin{array}{l}\text { Researcher - } \\
\text { Analyst at the } \\
\text { Institute for } \\
\text { National } \\
\text { Security Strateg }\end{array}$ & South Korea \\
\hline $\begin{array}{l}\text { Kim Dong- } \\
\text { soo }\end{array}$ & 1998 & Military officer & $\begin{array}{l}\text { Unknown } \\
\text { function }\end{array}$ & \\
\hline Kim Heung- & 2002 & IT Professor at the Kim Il Sung & Founder & Unknown \\
\hline
\end{tabular}




\begin{tabular}{|c|c|c|c|c|}
\hline kwang & & University & $\begin{array}{l}\text { directory } \\
\text { member of } \\
\text { North Korea } \\
\text { Intellectual } \\
\text { Solidarity }\end{array}$ & localization \\
\hline $\begin{array}{l}\text { Kim } \\
\text { Hyeong-soo }\end{array}$ & 2009 & $\begin{array}{l}\text { biophysicist, Institute of Kim Il } \\
\text { Sung Longevity (a.k.a the National } \\
\text { Security Sciences Institute - } \\
\text { Mansumugang Institute) }\end{array}$ & $\begin{array}{l}\text { Unknown } \\
\text { function }\end{array}$ & $\begin{array}{l}\text { Unknown } \\
\text { localization }\end{array}$ \\
\hline Kim In-tae & $\begin{array}{l}\text { Unknow } \\
\mathrm{n}\end{array}$ & Unknown function & $\begin{array}{l}\text { Researcher, } \\
\text { Institute } \\
\text { National } \\
\text { Security } \\
\text { Strategy } \\
\end{array}$ & $\begin{array}{l}\text { Unknown } \\
\text { localization }\end{array}$ \\
\hline $\begin{array}{l}\text { Kim Min- } \\
\text { kyu }\end{array}$ & 2009 & $\begin{array}{l}\text { Diplomat at the North Korean } \\
\text { embassy in Russia }\end{array}$ & $\begin{array}{l}\text { Unknown } \\
\text { function }\end{array}$ & $\begin{array}{l}\text { Unknown } \\
\text { localization }\end{array}$ \\
\hline $\begin{array}{l}\text { Kim So- } \\
\text { yeon }\end{array}$ & 1992 & $\begin{array}{l}\text { Director, Kim Il Sung Longevity } \\
\text { Institute (a.k.a the National } \\
\text { Security Sciences Institute) }\end{array}$ & $\begin{array}{l}\text { Unknown } \\
\text { function }\end{array}$ & $\begin{array}{l}\text { Unknown } \\
\text { localization }\end{array}$ \\
\hline $\begin{array}{l}\text { Kim } \\
\text { san }\end{array}$ & 2002 & $\begin{array}{l}\text { North Korean Trading Company } \\
\text { Official }\end{array}$ & $\begin{array}{l}\text { Unknown } \\
\text { function }\end{array}$ & $\begin{array}{l}\text { Unknown } \\
\text { localization }\end{array}$ \\
\hline $\begin{array}{l}\text { Kim Young- } \\
\text { il }\end{array}$ & 2006 & Unknown function & $\begin{array}{l}\text { PSCORE } \\
\text { Organization } \\
\text { Director (People } \\
\text { for Successful } \\
\text { Corean } \\
\text { Reunification) }\end{array}$ & $\begin{array}{l}\text { Unknown } \\
\text { localization }\end{array}$ \\
\hline $\begin{array}{l}\text { Kim } \\
\text { song }\end{array}$ & 1991 & Colonel, Korean People's Army & $\begin{array}{l}\text { Board Member } \\
\text { of Unification } \\
\text { Organizations }\end{array}$ & South Korea \\
\hline $\begin{array}{l}\text { Ko Young- } \\
\text { hwan }\end{array}$ & 1991 & $\begin{array}{l}\text { Diplomat, director of the African } \\
\text { Desk at the DPRK MOA, former } \\
\text { first secretary of the North Korean } \\
\text { embassy in Congo }\end{array}$ & $\begin{array}{l}\text { Board Member } \\
\text { of Unification } \\
\text { Organizations }\end{array}$ & South Korea \\
\hline $\begin{array}{l}\text { Ko Yong- } \\
\text { suk }\end{array}$ & 1998 & $\begin{array}{l}\text { Member of the Kim family, } \\
\text { younger sister of Kim Jong-un's } \\
\text { sister }\end{array}$ & $\begin{array}{l}\text { Unknown } \\
\text { function }\end{array}$ & South Korea \\
\hline $\begin{array}{l}\text { Kyong } \\
\text { Won-ha }\end{array}$ & 2002 & $\begin{array}{l}\text { Scientist, sometimes considered as } \\
\text { being the father of North Korea's } \\
\text { nuclear program }\end{array}$ & $\begin{array}{l}\text { Unknown } \\
\text { function }\end{array}$ & South Korea \\
\hline $\begin{array}{l}\text { Lee Myong- } \\
\text { kuk }\end{array}$ & 2002 & Kim Jong-il's bodyguard & Activist & Canada \\
\hline $\begin{array}{l}\text { Oh Young- } \\
\text { nam }\end{array}$ & $\begin{array}{l}\text { Unknow } \\
\text { n date }\end{array}$ & $\begin{array}{l}\text { Captain in State Security, } \\
\text { supposedly a relative of Marshal O } \\
\text { Jin-u }\end{array}$ & $\begin{array}{l}\text { Unknown } \\
\text { function }\end{array}$ & South Korea \\
\hline $\begin{array}{l}\text { Park Seung- } \\
\text { won }\end{array}$ & 1999 & $\begin{array}{lllll}\begin{array}{l}\text { Korean } \\
\text { general }\end{array} & \text { People's Army } & 2 \text { stars } \\
& & & \\
\end{array}$ & $\begin{array}{l}\text { Unknown } \\
\text { function }\end{array}$ & South Korea \\
\hline
\end{tabular}




\begin{tabular}{|l|l|l|l|l|}
\hline $\begin{array}{l}\text { Park Sang- } \\
\text { hak }\end{array}$ & 1999 & $\begin{array}{l}\text { Employee at a propaganda unit of } \\
\text { the Kim Il Sung Socialist Youth } \\
\text { League }\end{array}$ & $\begin{array}{l}\text { Activist, board } \\
\text { member } \\
\text { foundations. }\end{array}$ & South Korea \\
\hline $\begin{array}{l}\text { Ri Han- } \\
\text { yong } \\
\text { passed } \\
\text { away } \\
\text { 1997) }\end{array}$ & 1982 & Member of the Kim family & Businessman & South Korea \\
\hline Ri Kang & 1998 & Member of the Kim family & Businessman & United States \\
\hline $\begin{array}{l}\text { Seol Song- } \\
\text { ha }\end{array}$ & 2008 & $\begin{array}{l}\text { Foreign Trade Manager, Ministry } \\
\text { of the Korean People's Army }\end{array}$ & Journalist & $\begin{array}{l}\text { Unknown } \\
\text { localization }\end{array}$ \\
\hline $\begin{array}{l}\text { Seong Ha- } \\
\text { joo }\end{array}$ & $\begin{array}{l}2002 \\
\text { (left } \\
\text { North } \\
\text { Korea in } \\
1998)\end{array}$ & $\begin{array}{l}\text { Lecturer at the Kim Il-sung } \\
\text { University }\end{array}$ & Journalist & South Korea \\
\hline $\begin{array}{l}\text { Sin Yong- } \\
\text { hui }\end{array}$ & $\begin{array}{l}\text { Unknow } \\
\text { n date } \\
\text { hyong }\end{array}$ & Dancer at the Mansudae Theater & Actress & South Korea \\
\hline Song Byeok & 2002 \\
Thae Yong- & 2016 & $\begin{array}{l}\text { Aiplomat at the DPRK embassy in } \\
\text { UK }\end{array}$ & $\begin{array}{l}\text { Unknown } \\
\text { function }\end{array}$ & South Korea \\
\hline Russia family Fund manager in & $\begin{array}{l}\text { Unknown } \\
\text { function }\end{array}$ & South Korea \\
\hline
\end{tabular}

Source: own research (nicolaslevi.wordpress.com)

\section{Notes}

1. Each class is splitted in sub-classes. The haksim kyechung has 12 subclasses, the tongyo kyechung, 18, and the chokdae kyechung, 21. The first class represents $25 \%$ of the population. Tongyo and Chokddae $55 \%$ and $20 \%$ respectively. 